\title{
Отзывы, рецензии
}

УДК 343.915

DOI: $10.35750 / 2071-8284-2020-2-223-228$

Л. В. Готчина

доктор юридических наук, профессор

Санкт-Петербургский университет МВД России

Российская Федерация, 198206, Санкт-Петербург, ул. Лётчика Пилютова, 1

ORCID: 0000-0003-4477-6559. E-mail: lgotchina@yandex.ru

\section{Предупреждение вовлечения несовершеннолетних в незаконный оборот наркотических средств, психотропных веществ или их аналогов - предмет криминологического исследования молодых учёных}

Аннотация: На заседании диссертационного совета Д 203.017.02, созданного на базе Краснодарского университета МВД России, 5 марта 2020 г. прошла защита диссертации Кузиной Любови Сергеевны на тему «Предупреждение вовлечения несовершеннолетних в незаконный оборот наркотических средств, психотропных веществ или их аналогов», представленной на соискание учёной степени кандидата юридических наук по специальности 12.00 .08 - уголовное право и криминология; уголовно-исполнительное право. Диссертационный совет, заседавший под председательством доктора юридических наук, профессора А. В. Симоненко, единогласно принял решение о том, что диссертация Л. С. Кузиной представляет собой научно-квалификационную работу, которая имеет существенное значение для науки криминологии и соответствует требованиям Положения о присуждении учёных степеней, а также о присуждении Л. С. Кузиной учёной степени кандидата юридических наук по специальности 12.00 .08 .

Ключевые слова: предупреждение; вовлечение; незаконный оборот наркотиков; наркотизм; психотропные вещества, аналоги; несовершеннолетние; больные наркоманией; наркопреступность; возраст уголовной ответственности; детерминирующие факторы.

Для иитирования: Готчина Л. В. Предупреждение вовлечения несовершеннолетних в незаконный оборот наркотических средств, психотропных веществ или их аналогов - предмет криминологического исследования молодых ученых // Вестник Санкт-Петербургского университета МВД России. - 2020. - № 2 (86). - С. 223-228. DOI: 10.35750/2071-8284-2020-2-223-228. 


\section{Larisa V. Gotchina}

Dr. Sci. (Jurid.), Professor

Saint-Petersburg University of the MIA of Russia

1, Letchika Pilyutova str., Saint-Petersburg, 198206, Russian Federation ORCID: 0000-0003-4477-6559.E-mail: lgotchina@yandex.ru

\section{Prevention of involvement of minors in illegal trafficking of narcotic drugs, psychotropic substances or their analogues - subject of criminological research of young scientists}

Annotation: At the meeting of the dissertation Council D 203.017.02, created on the basis of the Krasnodar University of the Ministry of internal Affairs of Russia, on March 5 of 2020, Kuzina Lyubov Sergeevna defended her dissertation on the topic: «Prevention of involvement of minors in illegal trafficking of narcotic drugs, psychotropic substances or their analogues», submitted for the degree of candidate of legal Sciences in the specialty 12.00 .08 - criminal law and criminology; criminal enforcement law. The dissertation Council, which met under the chairmanship of doctor of law, Professor A. V. Simonenko, unanimously decided that L. S. Kuzina's dissertation is a scientific qualification work that is essential for the science of criminology and meets the requirements of the Regulations on awarding academic degrees, as well as on awarding L. S. Kuzina the degree of candidate of law in the specialty 12.00.08.

Keywords: prevention; involvement; illicit drug trafficking; narcotics; psychotropic substances, analogues; minors; drug addicts; drug crime; age of criminal responsibility; determining factors.

For citation: Gotchina L.V. Prevention of involvement of minors in illegal trafficking of narcotic drugs, psychotropic substances or their analogues - subject of criminological research of young scientists // Vestnik of St. Petersburg University of the Ministry of Internal Affairs of Russia. - 2020. - № 2 (86). - P. 223-228. DOI: 10.35750/2071-8284-2020-2-223-228.

Статья представляет собой отзыв на диссертацию официального оппонента, в котором подвергнуты анализу структура и содержание диссертации.

«В России проблема наркотиков давно переросла из медицинской в политическую и экономическую» $[1 ;$ с. 6]. Последняя связана в том числе и с наблюдаемым дефицитом трудовых ресурсов, восполняемых в основном за счёт молодого поколения, а конкретнее - за счёт миграционного населения, которое несёт не только новую культуру, но и криминальные проявления. В частности, несовершеннолетние становятся жертвами различных преступлений и вовлекаются в них. Этот процесс в России набирает обороты. Так, беспризорные несовершеннолетние входят в группу риска, представители которой при определенных условиях могут стать потерпевшими от полового насильника [2; с. 36] или быть вовлечены в организацию занятия проституцией [3; с. 72]. «Идея “легализации оружия" и насаждаемая идеология насилия, транслируемая ежедневно на всех каналах телевидения, выступают факторами воспроизводства деяний, предусмотренных статьями 222, 223 УК РФ, и криминальных сделок с оружием [4; с. 24], которые преобладающе совершаются молодежью и в отношении них; у несовершеннолетних формируется представление о том, что насилие - единственный метод получения желаемого, кто его применяет, тот выходит победителем в различных жизненных ситуациях. Состояние российского наркобизнеса вызывает потребность в “консолидации усилий правоохранительных органов разных стран по его предупреждению"» [5; с. 595].

Согласно данным авторского анкетирования В. В. Семёновой, «среди подозреваемых, обвиняемых и осуждённых за совершение преступлений, предусмотренных ст. $228^{1}-234^{1}$ УК РФ, 30 \% имели судимость (погашенную и непогашенную) за незакон- 
ный оборот наркотиков. В связи с этим назначение им наказания, не связанного с лишением свободы, не удержало их от совершения новых преступлений» [6; с. 167]. Высок процент наркорецидива ещё и потому, что часть наркопреступников больна наркоманией. Для них, кроме наказания, Уголовный кодекс РФ предусмотрел в статье $72^{1}$ возможность назначения курса лечения от наркомании и медицинской и (или) социальной реабилитации. Предложения об изменении законодательства по организации профилактики незаконного потребления наркотических средств и психотропных веществ, наркомании применительно к категории несовершеннолетних наркопреступников, больных наркоманией, хорошо описаны в работе А. А. Малыгиной [7, с. 11-14].

Уязвимость в наркотизме несовершеннолетних высокая. Их вовлечение в незаконный оборот наркотических средств, психотропных веществ или их аналогов представляет собой один из основных факторов увеличения показателей российской наркопреступности и наркозависимости подростков и детей. Начиная употреблять наркотики, они впоследствии активно включаются в их производство и распространение, получают преступную специализацию - наркоспециализацию. Такая тенденция однозначно представляет собой угрозу для национальной безопасности и повышает актуальность темы исследования молодого диссертанта Любови Сергеевны Кузиной.

Как справедливо отмечает сам автор, новое криминологическое знание о «полноценном» и всеобъемлющем вовлечении несовершеннолетних в незаконный оборот наркотических средств, психотропных веществ или их аналогов может предопределить подготовку оптимальной и адекватной стратегии в области организации соответствующей правоохранительной антинаркотической деятельности. Этим обстоятельством обосновывается актуальность предпринятого автором обозначенного криминологического исследования.

При этом многочисленные научные результаты в основном посвящены разработке проблемы предупреждения преступности несовершеннолетних, а также предупреждения наркопреступлений. В разное время этим проблемам посвящали свои научные труды Г. А. Аванесов, Ю. М. Антонян, М. М. Бабаев, Т. А. Боголюбова, В. И. Брылев, А. А. Габиани, Э. Г. Гасанов, Я. И. Гилинский, А. В. Готлиб, А. Я. Гришко, И. Н. Дружинин, Г. Н. Драган, И. И. Карпец, И. И. Курылев, В. Н. Кудрявцев, С. Я. Лебедев, А. А. Майоров, В. Б. Малинин, Г. М. Мерекутов, А. А. Музыка, С. С. Наумов, В. С. Овчинский, В. И. Омигов, М. Л. Прохорова, В. А. Плешаков, И. Н. Пятницкая, Л. И. Романова, А. Н. Сергеев, Н. А. Сирота, В. Н. Смитиенко, П. Н. Сбирунов, К. А. Толпенкин, А. В. Шеслер, В. М. Ялтонский и др.

В то же время в криминологической литературе сегодня довольно слабо освещена научная информация о современном состоянии вовлечения несовершеннолетних в незаконный оборот наркотических средств, психотропных веществ или их аналогов; об участии самих несовершеннолетних в организации такой преступной деятельности; о механизмах вовлечения несовершеннолетних взрослыми в незаконный оборот наркотиков и их потребление, а также вовлечения самими несовершеннолетними своих сверстников в указанную деятельность; наконец, о предупреждении подобных преступлений, совершаемых как взрослыми, так и несовершеннолетними. Перечисленные пробелы предопределили необходимость их восполнения в процессе нового криминологического изучения проблемы вовлечения несовершеннолетних в незаконный оборот наркотиков в диссертации Л. С. Кузиной. Поэтому степень её актуальности оценивается как высокая, востребованность результатов работы криминологической теорией и практикой правоприменения очевидна.

Не вызывают сомнений научные результаты, характеризующие научную новизну диссертации, направленные на совершенствование законотворческой и правоприменительной деятельности, обеспечивающей защиту несовершеннолетних от вовлечения их в незаконный оборот наркотических средств, психотропных веществ или их аналогов.

Впрочем, научная новизна диссертации определяется кругом рассматриваемых в ней проблем, а также содержанием предложенных автором подходов к их решению. В диссертации: 
- выявлены новые криминологические показатели преступлений, связанных с вовлечением несовершеннолетних в незаконный оборот наркотических средств, психотропных веществ или их аналогов, авторская оценка которых позволила определить более масштабное по сравнению с официальной уголовно-правовой регистрацией криминологическое состояние проблемы вовлечения несовершеннолетних в незаконный оборот наркотиков;

- определены и обоснованы новые закономерности и основные современные тенденции преступлений, связанных с вовлечением несовершеннолетних в незаконный оборот наркотических средств, психотропных веществ или их аналогов, и участия самих несовершеннолетних в организации и обеспечении такого оборота;

- сформулировано авторское определение «сетевой наркомаркетинг»;

- определена криминологическая специфика механизмов вовлечения несовершеннолетних в незаконный оборот наркотиков, отличающих их (механизмы) своей системностью и организованностью от традиционного вовлечения несовершеннолетних в иные преступления и иную антиобщественную деятельность, создающих новые предпосылки для совершенствования системы антикриминогенного предупреждения рассматриваемых преступлений и обеспечения защиты несовершеннолетних от них;

- теоретически обоснована универсальная модель вовлечения несовершеннолетних в такой незаконный оборот с установлением и оценкой в ней ролей взрослых и несовершеннолетних участников, стадий вовлечения, способов и приёмов, используемых вовлекателями на каждой из обозначенных стадий, позволяющая конкретизировать меры специально-криминологического (включая индивидуально-профилактическое) предупреждения преступной деятельности;

- разработан алгоритм последовательных профессиональных действий сотрудников правоохранительных органов, нацеленных на выявление, предупреждение, раскрытие и расследование преступлений, связанных с вовлечением несовершеннолетних в незаконный оборот наркотических средств, психотропных веществ или их ана- логов, в том числе совершаемых с использованием сети Интернет.

Результаты диссертационного исследования Л. С. Кузиной обладают необходимой теоретической и прикладной значимостью. Совокупность полученных в процессе его проведения результатов способствует развитию криминологического учения о противодействии незаконному обороту наркотических средств, психотропных веществ или их аналогов. Теоретические положения, выводы и рекомендации могут быть использованы в законотворческом процессе; в практической деятельности субъектов профилактики; в процессе дальнейших теоретических исследований; в учебном процессе образовательных организаций высшего образования юридического профиля при изучении «Криминологии», «Уголовного права», «Ювенальной криминологии», «Предупреждения органами внутренних дел преступлений и административных правонарушений несовершеннолетних» и «Виктимологии».

Особо следует подчеркнуть всесторонний характер проведенного исследования, последовательность содержащихся в нём предложений и выводов, чему во многом способствовала довольно удачная структура диссертации, которая состоит из введения, трёх глав, объединяющих восемь параграфов, заключения и списка литературы.

Результаты проведенного Л. С. Кузиной диссертационного исследования отличаются высокой степенью научной достоверности, которая обеспечена:

- использованием апробированной научной методологии (системного подхода, а также частнонаучных методов познания: историко-правового, формально-логического, сравнительно-правового, социологического и статистического);

- солидной теоретической основой, которая представлена как современной литературой по криминологии, так и международно-правовыми источниками.

Не может не впечатлить эмпирическая основа данного труда: широко представлена география научной выборки - Республики: Башкортостан, Калмыкия; Краснодарский, Ставропольский, Красноярский края; Астраханская, Архангельская, Белгородская, Брянская, Воронежская, Калужская, Калинин- 
градская, Курская, Липецкая, Московская, Нижегородская, Омская, Орловская, Пензенская, Ростовская, Самарская, Саратовская, Свердловская, Тамбовская, Томская, Ярославская области; города федерального значения Москва и Санкт-Петербург; Ямало-Ненецкий автономный округ; проанализировано 320 приговоров судов общей юрисдикции и мировых судей по исследуемым преступлениям; проведено анкетирование: 1) несовершеннолетних, с помощью информационнотехнологических возможностей социальных сетей (800 чел.); 2) 386 специалистов из числа сотрудников органов внутренних дел; 3) 284 социальных педагогов, учителей, психологов; интервьюирование 45 лиц, стоящих на учёте в наркологическом диспансере с диагнозом «наркомания» и добровольно проходивших лечение от наркотической зависимости в реабилитационных центрах. Столь качественный эмпирический фундамент придает весомость и убедительность авторским выводам, определяет их достоверность.

Работу отличают глубина и тщательность исследования рассматриваемых вопросов, строгая логика изложения, последовательная и убедительная аргументация соискателем собственных выводов. Соискатель продемонстрировал умение корректно вести научную дискуссию, последовательно доказывать собственную точку зрения, умение анализировать и обобщать нормативные и доктринальные источники, эмпирический материал.

Результаты научного исследования получили разнообразную апробацию. Его основные положения и выводы отражены в 19 опубликованных научных статьях, из которых 5 опубликованы в рецензируемых научных журналах и изданиях, указанных в перечне Высшей аттестационной комиссии при Министерстве науки и высшего образования Российской Федерации.

Принимая во внимание актуальность темы диссертации, высокий уровень её научной новизны, несомненную теоретическую и практическую значимость полученных результатов, можно заключить, что Л. С. Кузина полностью справилась с заявленными целью и задачами исследования. В то же время её диссертация не лишена отдельных недостатков, которые, к сожалению, являются неизбежными спутниками практически любого оригинального научного исследования по актуальной проблеме.

1. В положении 1 и пункте «б» положения 7.2, выносимых на защиту, диссертант предлагает снизить возраст уголовной ответственности за совершение преступлений, предусмотренных ст. 228 УК РФ, до 14 лет. Вместе с тем в тексте диссертации не приводится чёткая аргументация, свидетельствующая о такой необходимости. В нашем представлении возраст субъекта преступления следует оставить прежним.

2. В международной практике по предупреждению вовлечения несовершеннолетних в незаконный оборот наркотических средств, психотропных веществ или их аналогов наработан значительный опыт. Однако диссертант эти вопросы в своей работе не осветил.

3. В диссертации и автореферате указываются детерминирующие факторы преступлений, связанных с вовлечением несовершеннолетних в незаконный оборот наркотических средств, психотропных веществ или их аналогов. Среди них: низкий уровень материального положения достаточно большого количества граждан; коррупция; проблемы в семье; недостатки в общеобразовательной среде; низкий уровень правовой культуры у несовершеннолетних. В нашем понимании это факторы всей преступности. Хотелось бы услышать от диссертанта о заявленных факторах, характерных для исследуемого вида преступности.

4. В автореферате при описании криминологического портрета несовершеннолетнего, вовлечённого в незаконный оборот наркотических средств, психотропных веществ или их аналогов, заявлена характеристика «недостаточное образование», требующая авторского разъяснения.

Вместе с тем указанные замечания имеют частный характер и не ставят под сомнение научную состоятельность, а также актуальность подготовленной диссертации.

Раскрыв актуальность темы исследования, рассмотрев ее дискуссионные вопросы, Кузина Любовь Сергеевна представила на публичную защиту завершенную научноквалификационную работу, выводы которой имеют значение для науки криминологии, обладают научной новизной, теоретической и практической значимостью и открывают направления для нового научного поиска. 


\section{Список литературь}

1. Гаврилов В. Г., Готчина Л. В., Диденко В. И. и др. Выявление и предупреждение незаконного оборота наркотиков. - Белгород: БелЮИ, 2006. - 208 с.

2. Готчина Л. В., Логинова Л. В. Уголовно-правовая и криминологическая характеристика преступлений против половой неприкосновенности и половой свободы несовершеннолетних : монография. - Москва: Юрлитинформ, 2015. - 192 с.

3. Готчина Л. В., Курилова Е. Н. О некоторых аспектах квалификации преступлений, предусмотренных статьей 241 УК РФ // Проблемы правоохранительной деятельности. - 2016. - № 1. - С. 72-76.

4. Готчина Л. В., Кокин Д. М. Некорыстный оборот оружия : монография. - Москва: Юрлитинформ, 2017. - 152 с.

5. Готчина Л. В. Международное законодательство в сфере предупреждения наркопреступлений, совершаемых несовершеннолетними, молодёжью и в отношении них // Lex Russica (Русский закон). - 2014. - T. 96. - № 5. - C.594-606. DOI: 10.7256/17295920.2014.5.9460.

6. Семёнова В. В. Уголовная ответственность за склонение к потреблению средств и веществ, представляющих угрозу здоровью населения : дис. ... канд. юрид. наук: 12.00.08 / Семенова Виктория Вячеславовна. - Санкт-Петербург, 2019. - 231 с.

7. Готчина Л. В., Малыгина А. А. Назначение наказания и мер медицинского характера лицу, признанному больным наркоманией : монография. - Москва: Юрлитинформ, 2017. - 163 с.

\section{References}

1. Gavrilov V. G., Gotchina L. V., Didenko V. I. et al. Detection and prevention of illicit drug trafficking. - Belgorod, 2006. - 208 p.

2. Gotchina L. V., Loginova L. V. Criminal-legal and criminological characteristics of crimes against sexual integrity and sexual freedom of minors: monograph. - Moscow: Yurlitinform, 2015. - 192 p.

3. Gotchina L. V., Kurilova E. N. On some aspects of the qualification of crimes under article 241 of the criminal code of the Russian Federation // Problems of law enforcement. 2016. - № 1. - Pp. 72-76.

4. Gotchina L. V., Kokin D. M. Non-Profit turnover of weapons: monograph. - Moscow: Yurlitinform, 2017. - 152 p.

5. Gotchina L. V. International legislation in the field of prevention of drug crimes committed by minors, youth and in relation to them // Lex Russica (Russian law). - 2014. T. 96. - № 5. - Pp. 594-606. DOI: 10.7256/1729-5920.2014.5.9460.

6. Semyonova $V$. V. Criminal liability for inducing the consumption of funds and substances that pose a threat to public health: dis. ... cand. the faculty of law science: 12.00 .08 / Semenova Victoria Vyacheslavovna. - Saint Petersburg, 2019. - 231 p.

7. Gotchina L. V., Malygina A. A. The imposition of punishment and measures of a medical nature to the person recognized as drug monograph. - Moscow: Yurlitinform, 2017. $-163 \mathrm{p}$.

(С) Готчина Л. В., 2020

Статья поступила в редакцию 10.03.2020 г. 